\title{
PLANT COLLECTION IN BOGOR BOTANICAL GARDEN AS A SOURCE OF FUNCTIONAL FOOD
}

\author{
SYAMSUL HIDAYAT \\ Research Center for Plant Conservation and Botanic Gardens-LIPI, Bogor, 16122, Indonesia
}

Email: hidayatkbri@yahoo.com

Accepted March 16, 2021 / Approved May 18, 2021

\begin{abstract}
Plant collection in Bogor Botanical Garden (BBG) has various potentials, one of which is as a food source. However, not all food produced from plants can be claimed as functional foods. This study analyses the potential of plants kept in the collections of BBG as functional foods and medicine sources with nutritional and health values. Literature studies have been carried out related to nutrition value and active substances owned by these plants, while data related to health claim was based on the results of ethnobotany studies, especially the use of medicinal plants by 28 ethnics in Indonesia. The results suggest 168 species of the BBG collection which can be claimed as a source of functional food which can be categorized into seven main categories. Among these plants are species classified as threatened or endangered such as Mangifera casturi, Vanilla planifolia, Pterocarpus indicus, Borassus flabellifer, Cycas rumphii, Dillenia philippinensis, and Litchi chinensis.
\end{abstract}

Key words: BBG, functional food, threatened species

\section{INTRODUCTION}

The role of Bogor Botanical Garden (BBG) as a source of food plant collection has begun since its establishment in 1817. According to its history, BBG was inseparable from the development of Bogor city as a center for agricultural and horticultural development in Indonesia. Plant species from various regions in Indonesia have been collected in Bogor Botanical Garden. Before planting it in the garden, plants collected from various regions are acclimatized first by carrying out maintenance and treatment activities in the nursery as an adjustment stage to the new climate. Some plant species originating from acclimatization in the Bogor Botanical Garden now have developed into main crops in the field of food such as palm oil, cocoa, and sugar cane, as well as medicinal plants and fruit trees.

At present, BBG collections include more than 3000 species originating from various regions in the world, specifically from Malay Archipelago. From these collections, only a few are known to have economic benefits for the community, both conventional and commercial. Plant species that have economic value in the community, in general, are species that produce food or medicines. In BBG, there are more than 100 species of plants that are potentially used as food (some parts of the plant have traditionally been a source of food), and some of them are classified as rare fruit plants. Meanwhile, based on literatures studies, there are more than 700 species in BBG collections that are potentially categorized into medicinal plants. However, not all of these plants has data on nutrition/active ingredients and benefits, while not all medicines produced from medicinal plants can be consumed orally as food or health drinks. It has been hypothesized that there are many species potentially useful as food or medicine source in BBG collections (hereafter, the term these species refers to "functional food plants").

The definition of functional food in Indonesia refers to Regulation of the Head of Indonesian Drug and Food Control Agency (BPOM) number HK 00.05.52.0685 dated January 27, 2005. In Chapter I (general provisions) article 1, functional food is defined as processed food containing one or more components that have certain physiological functions proven to be harmless and beneficial to health, based on scientific studies. Actually, functional food cannot be necessarily processed (Howlett, 2008), and food that is recognized as functional food is one that is consumed as conventional food providing health benefits and reducing disease risks. For this reason, natural food forms such as fresh fruits or vegetables that are not processed or modified can be categorized as functional food. The existence of nutritional claims, health claims, and claims to reduce the risk of disease make functional food important (European Parliament \& Council of Europe, 2006). Nutritional claims imply that a food has beneficial nutritional ingredients; likewise, health claims imply that consumption of a certain food category or certain foods or the contents in it will reduce the risk of certain diseases in humans.

The purpose of this study is to explore the potential of BBG plant collection as a source of functional food. This plant has been utilized by several ethnic groups in Indonesia in traditional medical practice. It is hoped that with this potential being revealed, BBG plant collection can be utilized as alternative sources of food and functional food in the future. 


\section{RESEARCH METHOD}

The study was carried out by conducting an inventory of BBG plant collection especially plant collection that is potential as food source and recapitulating data on medicinal plants from 28 ethnics. Inventory is done by recording medicinal plant species that exist in BBG directly in the field. The species recorded were then matched with a list of medicinal plants that had been recapitulated from 28 ethnics. These 28 ethnics are considered as a representation of ethnic groups in seven Indonesian bioregions. Each region represented by four main ethnic groups. Most of the medicinal plant data is the result of ethnobotany studies conducted by the author (Hidayat, 2005; Hidayat, 2011; Hidayat, 2013; Hidayat, 217; Hidayat and Cahyaningsih, 2017) and a small portion of other data is the result of studies by other researchers (Widyastuti and Widayat, 2013; Susiarti et al., 2015; Ibrahim, 2016; Arini, 2017; Kotala and Firdhausi, 2019). From the recorded medicinal plants, only the species used orally (in the form of food /drink) were selected as the primary data for this paper. The selected species were then checked for their presence in the BBG, resulting in a list of $\mathrm{BBG}$ collections with potential food, based on empirical data from communities, which has an influence on health. Furthermore, based on this list, a literature study was conducted related to the presence of active substances and nutrient content of the species concerned. One important data related to plant conservation is the conservation status of a species. Therefore, checking the conservation status of each species based on the 2019 IUCN category was also carried out.

\section{RESULT AND DISCUSSION}

\section{Food Category}

Based on the modified food category from the FAO-WHO (2018) and the Decree of Head of Drug and Food Supervisory Agency, Ministry of Health of the Republic of Indonesia (2006), food categories in this study can be divided into seven major groups, namely staple foods, nuts/ seeds, vegetables, fruits, spices, herbs, and food/beverage ingredients as well as one more group as miscellaneous. A total of 168 species of BBG plant collection have been recorded as potential functional foods based on health information obtained from 28 ethnic groups in Indonesia and nutritional information or active substances from several literatures or scientific references. In summary, the results obtained in this study are presented in the following table.

Of the 168 species of plant collections that are potential as functional foods, some species fit into more than one category. For example papaya can be included in the category of fresh fruit or vegetable. In detail, each food category is presented as follows.

Table 1. Categories of plants for functional food sources, BBG plant collection.

\begin{tabular}{|c|c|c|c|c|c|}
\hline Nu. & Categories & $\begin{array}{l}\text { Number of } \\
\text { spesies }\end{array}$ & $\begin{array}{l}\text { Threatened species } \\
\text { (IUCN 2019) }\end{array}$ & $\begin{array}{l}\text { Cultivated } \\
\text { species }\end{array}$ & Wild species \\
\hline \multirow[t]{5}{*}{1} & Staple & & & & \\
\hline & a. Cereal & a. 2 & Amorphophallus paeoniifolius, & a. 0 & a. 2 \\
\hline & b. Seed & b. 2 & Cycas rumphii & b. 1 & b. 1 \\
\hline & c. Yam/bulbs & c. 4 & & c. 3 & c. 1 \\
\hline & d. Sago & d. 5 & & d. 0 & d. 5 \\
\hline 2 & Nut /seeds & 15 & $\begin{array}{l}\text { Parkia timoriana, Nypa } \\
\text { fruticans, Caryota mitis }\end{array}$ & 1 & 14 \\
\hline \multirow[t]{3}{*}{$3 . \mathrm{a}$} & Vegetables & & & & \\
\hline & a. Raw & a. 23 & Pterocarpus indicus, & a. 10 & a.13 \\
\hline & b. Processed & b. 14 & Scorodocarpus borneensis & b.7 & b.7 \\
\hline $3 . b$ & Other vegetables & 17 & Nymphaea lotus & 2 & 15 \\
\hline \multirow[t]{3}{*}{4} & Fruits & & Dillenia philippinensis, & & \\
\hline & a. Fresh & a. 74 & Borassus flabellifer, Mangifera & a. 27 & a. 47 \\
\hline & b. Processed & b. 20 & $\begin{array}{l}\text { casturi, Litchi chinensis, } \\
\text { Rhodomyrtus tomentosa }\end{array}$ & b. 4 & b. 16 \\
\hline 5 & Spices & 12 & Cratoxylum cochinchinense & 8 & 4 \\
\hline \multirow[t]{3}{*}{6} & Herbs & & & & \\
\hline & a. Boiled & a. 21 & Lunasia amara & a.11 & a. 10 \\
\hline & b. Direct consumption & b. 4 & & b. 3 & b. 1 \\
\hline 7 & Food / beverage ingredients & 15 & & 8 & 7 \\
\hline 8 & Others/miscellaneous & 12 & $\begin{array}{l}\text { Vanilla planifolia, Pinus } \\
\text { merkusii, }\end{array}$ & 6 & 6 \\
\hline
\end{tabular}




\section{a. Staple food}

Based on the data collected, there are 13 species that can be included in the functional food group as the staple food category. In general, currently the staple food of Indonesian people is rice derived from paddy plants (Oryza sativa). However, there are still some ethnic groups that use tubers, seeds or other parts of plants as staple foods such as sago and cassava. Based on data from ethnobotany studies in Nusa Tenggara and Papua regions, there are a number of plant collection in BBG that is potential to be the main source of carbohydrates besides rice.

Samples of tubers that have been widely consumed by Indonesian people are taro (Colocasia esculenta), sente (Alocasia macrorrhizos), and suweg (Amorphophallus paeoniifolius). Taro is a tuber that is already popular in Indonesia, especially in West Java, precisely in Bogor city. In Ministry of Forestry Regulation P.35/2007 concerning Non-Timber Forest Products/NTFPs, taro plants are grouped into tubers and are one of the plants that are often planted on agroforestry lands as an alternative food crop. The other type of taro is sente, this tuber is widely consumed by people in rural Java, Sulawesi and Lombok. Flavonoids contained in sente tubers are reported to have biological effects as antioxidants, antibacterial and antidiarrheal (Yuliana and Fatmawati, 2018). Meanwhile Suweg bulbs are consumed traditionally by Sundanese and Javanese people who also believe that consuming these tubers can reduce glucose levels for diabetics.

In addition to tubers, an alternative food that has become staple food for several ethnic groups in Indonesia is sago. Sago can be obtained from the stems of Metroxylon sago, Cycas rumphii, and Barringtonia racemosa. The main types of sago in Indonesia are those produced from Metroxylon sago plants. Sago plants are naturally spread almost on every island in Indonesia with the largest area centered in Papua, while semi-cultivated sago is found in Maluku, Sulawesi, Kalimantan and Sumatra. Sago plants has always had an important meaning for people's lives, especially in eastern Indonesia, both as a source of staple food and as a building material. In Papua, aside from being a staple food, sago is also believed to be a medicine for stomachaches and chicken pox. In the future, sago flour can be widely used for industrial purposes, such as bread, noodle, cake, high-fructose syrup, adhesive, and biodegradable plastics.

Another staple food alternative is cereals. One of the cereals obtained from seeds is jali derived from the Coix lacryma-jobi plant. Seyie et al. (2018) reports that Coix lacryma jobi is superior to major crops like rice, maize, wheat etc. in terms of nutritive and nutraceutical values. Local people in Indonesia process jali into various foods such as pilav, porridge, various kinds of cakes (both wet and dry), and fermented foods such as tapai. Aside from being a staple food source, jali is very potential as a functional food and medicinal plant.

From aquatic plants, there is Sagittaria sagittifolia, that is regarded as one of the best ethno-nutraceutical plant because it possesses various therapeutic properties in their biofunctional parts leaves and tubers (Rao and Pandey, 2017). In Lombok, this plant is known as keladi air, and is used in treating digestive disorders.

Other plants that are potential as a source of carbohydrates and have not been widely used are nipah (Nypa fruticans). This plant is commonly found in South Sumatra and East Kalimantan with limited use. This palm trees can produce 2.55 tons/ha of fruit flesh which can be processed into palm flour of 1.99 tons/ha. The content of nipah flour is quite good and is equivalent to rice, with the carbohydrate content of $75.25 \%$. Nipah flour is high in fiber with low fat and calorie content which are potential as food source for people on a diet. Nipah flour contains nine of the twelve types of essential amino acids, namely histidine, arginine, threonin, valine, methionin, iso-leucine, leucine, phenyl alanine and lysin that are needed by the human body (Heriyanto et al., 2011).

\section{b. Nut and seeds}

Nut have been widely consumed by the people of Indonesia, the most famous of which are cashews and macadamia. These two nut-producing plant species are found in BBG. Besides these two species, there are still many nut-producing plants which are listed in BBG plant collection that have not been used optimally in the community, such as galo, walnuts and ketapang. From ethnobotany data, there are at least 15 collections of nutproducing plants in BBG such as Allophylus cobbe, Anacolosa frutescens, Myristica fatua, Pandanus polycephalus, Parkia timoriana, and Pentaspadon motleyi. Sundanese people consume A.cobbe fruit, which is also famous in other countries such as India and Peru as a traditional beverage ingredient (Chavan and Gaikwad, 2016). The fruits of Anacolosa frutescens with seeds are used as food, it is reported to possess antiinflammatory activity and analgesic property (Alimboyoguen et al., 2014). Kedawung seeds (Parkia timoriana) can be consumed by roasting or made into a powder like coffee, and is believed by the people of East Java to cure a stomach bloating. Meanwhile, plajau seeds (Pentaspadon motleyi) are consumed by the people of Kalimantan as a snack and can also treat shortness of breath. Both Kedawung seeds and Plajau seeds have high carbohydrate and protein contents. Kedawung seeds contain $22 \%$ carbohydrates, $24.6 \%$ fat and $42.3 \%$ protein while plajau seeds contain protein at $9.66 \%$; fat $14.52 \%$; and carbohydrates $23.2 \%$. Thus the use of two medicinal seeds as alternatives of functional food seems to be reasonable.

\section{c. Vegetables}

In general, vegetables come from horticultural plants, usually in the form of leaves. Although most 
botanical garden collection plants are not horticultural plants, many of the collection plants have traditionally been used as raw vegetables (fresh vegetables) and processed vegetables. We identified 37 species of BBG plant collection whose leaves can be used as a vegetable material both processed and raw/fresh. Some woody plants such as Adenanthera pavonina, Altingia excelsa, Anacardium occidentale, Mangifera caesia provide leaves that can be enjoyed by certain ethnic groups as raw vegetable material. The Sundanese ethnic group, in general, likes the young fresh vegetables of the species to be consumed as a supplement with rice or to be consumed singly as a body freshener or healthener. Meanwhile, Limnocharis flava, Monochoria hastata, Morinda citrifolia, Moringa oleifera are examples of plants that produce vegetables to be processed.

Apart from leaves, there are other parts of the plant that can also be eaten either directly or after processing. There are 17 plants in the BBG collection whose specific parts can be processed as potential vegetables, such as shoots from several bamboo and palm species, tubers and stems from Colocasia esculenta, flowers from Erythrina fusca, Ixora javanica, fruits from Bouea macrophylla and Carica papaya. Bogor Botanical Garden also has a collection of fern plants such as Acrostichum aureum and Ceratopteris thalictroides that can be processed into vegetable food. Certain fern species are consumed as food or as folk medicine in several countries to treat various ailments (Chen et al., 2015). Sea Fern (Acrostichum aureum) which is used in medicine in Sulawesi and Timor is rich in antioxidants (Hanin and Pratiwi, 2017). Meanwhile, Malay people in Sumatra and Kalimantan are consuming $C$. thalictroides as a vegetable and as a diabetes medicine. This is understandable because based on research by Chen et al. (2015) this plant contains Pterosin which is very useful as an antidiabetic. Many species of ferns are consumed as vegetables by the Dayak community in Kalimantan. For example the Dayak Kenyah community in East Kalimantan cooks young leaves and stems of Cyathea contaminans as well as some leaves from fern families such as Diplazium, Nephrolepis, and Stenochlaena. In fact, in Central and West Kalimantan, vegetable fern species (Stenochlaena palustris) which are rich in vitamins $\mathrm{A}$ and $\mathrm{C}$ and minerals (iron, calcium) have been sold in the form of dry food packages called kelakai and in some areas consumed as curry vegetables or made urap (leaves mixed with shredded coconut).

d. Fruit

Verheij and Cornell (1992) reported that there are 400 species of edible fruits in Southeast Asia. Indonesia is a center of species diversity and genetic resources for fruits, including tropical exotic fruits. Fruits contain a variety of vitamins, minerals and fiber, so consuming fruit can maintain health, protect the body from the effects of aging and reduce the risk of various diseases. Thus it is potential to use exotic fruits as functional food or processed fruit to increase the added value of the fruit.
As an example is Punica granatum or pomegranate, a nutrient dense food source rich in phytochemical compounds. Pomegranate, is popularly consumed as fresh fruit and juice, beverages, food products (jams and jellies) and its extracts used as botanical ingredients in herbal medicines and dietary supplements (Rowayshed et al., 2013). One more example is the salak fruit (Salacca zalacca). Salak is a good source of carbohydrate and dietary fibre. The fruit pulp has been reported to possess high antioxidant capacity as compared to other exotic fruits. The pulps of salak fruit are mainly consumed either freshly or as juice. They are also processed into dried fruits, pickles, chips, canned in syrup as well as added as an ingredient in local food (Saleh et al., 2018).

Some species of fruit plants are found in the BBG, but not all fruits can be eaten and have health claims in the community. In this study, fruit is the largest food category found in the BBG. At least 74 fresh fruitproducing species can be obtained that can be claimed as potential functional food fruits, while 20 other fruits must be processed before they can be consumed. Most of the fruit plants in the BBG are species that have not been cultivated in the community. In fact, one species of fruit tree is declared extinct in nature, namely Mangifera casturi originating from South Kalimantan. In addition, there are many species of fruit plants that are starting to be difficult to find around the community such as Dillenia philippinensis, Litchi chinensis, and some species of fruit from the genera Aglaia, Syzygyum and Mangifera. Lepisanthes amoena fruit is also edible, but it is not well known, based on Salusu et al. (2017) research, the seed and the flesh of this fruit had a phytochemical content and antioxidant activity. Some species produce fruit that is not commonly consumed, if it is found in the wild. These fruits can be very beneficial because they are rich in antioxidants and as a refresher relieving fatigue; such as Capparis micracantha, Cynometra cauliflora, Dillenia indica, Eriobotrya japonica, Flacourtia jangomas, Flacourtia rukam, Glycosmis pentaphylla, and Molineria capitulata. Some Indonesian people use fruit of $M$. capitulata as a sweetener replacing sugar. It is safe to be consumed by diabetics patient since it contains low or no sugar (Briliani et al., 2018). In fact, immature fruit such as Flacourtia rukam can be consumed as a medicine for diarrhea and dysentery (Ragasa et al., 2016). Dillenia indica is found to possess analgesic, anti-diabetic, antimicrobial,anti-bacterial,anti-diabetic,anti-oxidant, and hair waving activity (Amritveer et al., 2016).

There are some fruit plants in the BBG which also function as herbs, such as Averrhoa spp., Annona spp., Artocarpus spp., and Citrus spp. The leaves and fruits of Averrhoa carambola have been used in folk medicine as an appetite stimulant, a diuretic, relieving fever as well as in the treatment of malaria. A. carambola commonly known as star fruit or carambola, is a tree originally from Asia which has become acclimatized in many tropical countries (Moresco et al., 2012). Fruit of Annona muricata has been used in traditional medicine in many 
countries as antiviral, antinociceptive, anti-inflammatory and antihyperglycemic properties (Ayele, 2018) while the fruits of $A$. squamosa, are reported to be a good tonic and have the ability to enrich blood and to increase muscle strength (Ma et al., 2017). Some fruits of Artocarpus are great source of carbohydrate and it is low fat. They can substitute partially wheat flour in many products such as snacks, pastries, bread and contain numerous beneficial biologically active compounds that show various biological activities including antibacterial, antitubercular, antiviral, and antifungal (Sikarwar et al., 2014). Meanwhile, many pharmacological studies have been conducted to investigate the properties of Citrus in an attempt to authenticate its use as a multipurpose medicinal agent (Chaudhari et al., 2016).

e. Spices

From this study, 13 species of spices that can be claimed as functional food sources have been obtained. Some of them are already popular in the community such as tamarind (Tamarindus indica), pangi (Pangium edule), and salam (Syzygium polyanthum) which are commonly used as spices, as well as nutmeg (Myristica fragrans) and pepper (Piper betle) as a food flavoring source. Besides functioning as a spice, tamarind and nutmeg are often found as fruit that is packaged into candied fruits for consumption as a healthy snack. Ripe tamarind fruit contains protein, fat, various minerals and vitamins such as A, B and C. Meanwhile, the main part of nutmeg (fruit flesh) is thick and weighs more than $70 \%$ of the overall weight of the fruit, yellowish white, filled with dilute gummy liquid, It tastes sour and has astringentic properties. Therefore, immature nutmeg, even if cannot be consumed directly, can be processed into various food products.

\section{f. Herbs}

Various ways of traditional medicine have been consumed for years by Indonesian ethnic communities. This is related to the richness of Indonesia's biological resources, especially plants. The BBG collected many plants which are potential for medicinal use and at least 764 species were documented as traditional medicinal ingredients. Of these hundreds of species, only a few of them are used orally either as food or drinks. This study obtained 21 species that are commonly used as ingredients of medicinal stew or herbal medicine in several ethnics, as well as four other species consumed directly. One of them is Lunasia amara which has not listed yet in IUCN red list even though its presence in nature is strongly eroded so that the Indonesian Biodiverity Strategy and Action Plant (IBSAP) categorized it as a group of rare plants. This species is believed to be an aphrodisiac in some ethnics and as a cure for malaria and hepatitis for other ethnics. Another wild threatened species that is widely used is Arcangelisia flava. A. flava has been widely used by Indonesian ethnics as a drug for hepatitis and malaria. The extract is also known to have sufficiently effective capability in lowering total cholesterol levels (Purwati et al., 2018). One more widely used plant is lampeni (Ardisia humilis); It is used for various purposes including food supply obtained from its fruit and young leaves. The fruits and leaves of lampeni are sour in terms of taste. That such sour taste is possibly caused by the presence of vitamin C (Lestari and Setiawati, 2018).

From the fern group, there are several species used as herbs. The most common is a bird's nest fern (Asplenium nidus). According to Jarial et al. (2018), the fern A. nidus is a rich source of anti-bacterial, antioxidant and anti-cancer phytochemicals. In Lombok, a decoction of A. nidus is used to treat high blood pressure.

Some species of aquatic plants that generally function as ornamental plants, also function as herbal plants as well as food sources. An example of these species is lotus species. According to Khasanah et al. (2019), almost all parts of the lotus plant can be used as food including rhizomes, leaves and stems, flowers and stamens, seeds and buffer flowers such as wasp nests/sponges (receptacles), and seed buds can be used for treatment. Lotus contains several different chemicals in each part. Lotus leaf is often used in traditional Chinese medicine. These leaves are useful for reducing heat, headaches and diarrhea. Apart from leaves, lotus seeds are also a potential food source because they are rich in protein content. Various cakes, drinks or puddings are more fragrant and savory by adding lotus seeds. Aside from its savory taste, these seeds are also beneficial for heart, spleen and kidney health (Khasanah et al., 2019)

\section{g. Source of healthy drinks}

Aside from being a source of traditional medicine, some plant species found in BBG collection are potential as a source of healthy drinks: for examples Cratoxylum cochinchinense leaf tea, Aglaia odorata and Artabotrys hexapetalus flower tea, Caesalpinia sappan bark tea, and Arenga pinnata palm sap known as tuak, as well as fresh drinks such as grass jelly from leaves of Cyclea barbata, Saccharum officinarum sugarcane, and Rosela tea from flower of Hibiscus sabdariffa. In many countries of the world, the stem pulp of $S$. officinarum (sugarcane) is consumed as a snack due largely to its sweet taste occasioned by high sucrose content. A study conducted by Williams et al. (2016) indicated the relative presence of alkaloids, saponins, flavonoids, hydrogen cyanide and tannins in the sugarcane. Data from the study suggest that sugarcane stem pulp could be suitable for use in rehydration and as a functional food plant. Some plants in BBG collection are famous for its taste like chocolate Theobroma cacao and vanilla Vanilla planifolia. There are also some species that are still found in wild and are rarely used, such as Rhodomyrtus tomentosa or in some areas known as karamunting. Karamunting fruit can be used in making food products such as syrup. Red to blackish ripe karamunting fruit contains anthocyanin compounds, is a natural pigment that gives red color and 
has high antioxidant properties (Rifkowati et al., 2018). Leaves of collection plants are used for healthy drinks such as Guazuma ulmifolia and Blumea balsamifera. Sembung or B. balsamifera has promising prospect as antihypertensive-functional-drink, that is widely consumed by Balinese people (Kusumawati et al., 2018).

h. Miscellaneous

This group is a number of plant species that has the potential to produce food supplementary ingredients such as food flavorings, fragrances, dyes and sweeteners (sugar). BBG has at least 12 species of plants that are included in this group. An example of these species is the oil from Vanilla planifolia and Pinus merkusii used as a flavoring of various foods. Cordyline fruticosa root, besides being used as a liver drug, also functions as a food sweetener. In addition, there are also certain parts of plant species which can be used as snacks such as candies from young shoots of Euphorbia antiquorum, fruits of Nypa fruticans, and flowers of Plumeria rubra.

\section{Conservation value}

Revealing medicinal and nutritive values of plants is not sufficient to fully assess their potential as functional food, as economical and conservation aspects shall be considered too. Some of the potential plants mentioned above are included in the category of threatened species. Based on the IUCN Red List of Threatened Species (2019), from the list of food potential plants obtained from this study, there was at least one species classified as extinct in its habitat (Extinct in the wild), namely Mangifera casturi. Some other collection plant species are categorized as follows, three spesies as Endangered plant, namely Vanilla planifolia, Pterocarpus indicus, and Borassus flabellifer; four species are included in the Vulnerable category, namely Cycas rumphii, Dillenia philippinensis, Litchi chinensis, Pinus merkusii; three species are categorized as Near threatened, namely Aglaia edulis, Aglaia odorata, and Dimocarpus longan, and 51 other species are categorized as Least Concerns.

Kasturi mangoes are no longer found in their natural habitat. According to Darmawan (2015) the potential of kasturi mangoes is less able to develop into a national superior fruit due to several constraints such as the very small flesh of the fruit while the size of the seeds is large, the age of the plant to bear fruit is quite long, and the harvest period is short. One way to overcome this obstacle is to make various efforts to modify plant cultivation, either by reducing the size of the seeds using genetic techniques and plant breeding, or by increasing the volume of fruit flesh by grafting with sweet fragrant mango plants as the rootstock. The success of the experiment to improve the quality of the kasturi mangoes so as to produce a lot of fruit flesh will spur the community to cultivate this plant. Finally, the kasturi mango can be better known by the public so that it can increase the biodiversity of mango plants in Indonesia. Other Indonesian native plants but with limited distribution to Sumatra is Pinus merkusii; besides its wood, in Aceh Province its sap is also used as a flavoring food such as vanilla. Pinus merkusii is the only surviving member of the genus that naturally extends its distribution from south to equator. However, in recent years, unsustainable extraction for timber, deforestation, clear felling, and logging have built up the pressure on the habitat of Pinus merkusii and as a result its population is decreasing significantly (Bharali et al., 2012).

The rare plants mentioned above include plants originating from abroad, but their existence is quite important for Indonesia. For example Lychee plants; since October 13, 2014 based on the decision of the Gianyar Regency DPRD number 18 of 2014, Lychee plants were proposed and established as a representative of the flora of Gianyar Regency (Saptayana et al., 2017). Another example is Dillenia philippinensis, which is originally from the Philippines. this species has many uses and is rather difficult to find in the wild. According to Lumeran (2016), their seeds do not germinate in its natural habitat due to its hard seed coat. The fruits are utilized as hair cleanser, an excellent source of jam, sauce, and fish flavourings. The acid juice of the fruits when mixed with sugar is used to cure cough.

Beyond the conservation status as explained above, most species recorded are wild species obtained from forests, fields or non-garden land. Of the 168 species, there are 98 species that belong to non-cultivated plants or are still growing in the wild. This must also be a concern as mass collection of these plants puts their sustainable regeneration under a clear risk, whilst there are no attempts of their cultivation. Some species are found in area of intensive land cultivation and this is another threat to their existence. According to the expansion of agricultural land, the conversion of forest has been the most common practise in many part of the world until today, and this can lead to a tremendous loss of biodiversity and environmental destruction (Sukara, 2014). Land use changes can affect many species (Mudiana, 2016). Actually, there are other plants in BBG collection that have potential to be functional food, but based on empirical data from Indonesian ethnics, there have not been any claims recorded. Health claims may be obtained on an empirical basis from ethnic groups outside Indonesia or based on general medical data. For example the sausage tree Kigelia africana, twin coconut Lodoicea maldivica., and walingi Typha angustifolia. Lodoicea maldivica is one of the species originating abroad, precisely from the Seychelles islands and is categorized as endangered plant. This endemic plant is even now known to be extinct in its habitat and is traditionally posted as an aphrodisiac (Damania, 2013). The fruit, which contains carbohydrates, protein, and vitamins, is used in China as a cough medicine and cooked as a soup (Mak and Mok, 2011). Kigelia africana originating from Africa and its conservation status is least concern (LC) has the potential to be an anticancer 
and treat leukemia. The bark, fruit and leaves have an active ingredient called lapakol (Olufemi et al., 2017), and for some regions in Africa, it is used as a vegetable because it is rich in minerals (Glew et al., 2010). Meanwhile, young shoots and rhizomes of Typha angustifolia can be cooked as a vegetable, besides being rich in carbohydrates this vegetable also functions as a diuretic and astringent (Fruet et al., 2012) and can be used for a variety of treatments because they contain antibacterial and antifungal activities (Varghese et al., 2009).

\section{CONCLUSION}

Our ethnobotanical review revealed 168 plant species of BBG collection that can be claimed as functional food sources due to the presence of active substances which are beneficial for health and valuable nutrients. Of these 168 species, 98 are wild and many of them are included in the category of endangered plants while one species has been even declared as extinct in the wild. These potential plants shall be further examined whether their mass use will threaten their existence, or whether their cultivations is feasible.

\section{ACKNOWLEDGEMENT}

I would like to express our special thanks of gratitude to Ms. Rizdika Mardiana for editing this manuscript.

\section{REFERENCES}

Alimboyoguen AB, Castro-Cruz KA, Shen CC, Ragasa CY. 2014. Chemical constituents of Anacolosa frutescens. Research Journal of Pharmaceutical, Biological and Chemical Sciences. 5(5): 1189-1191.

Amritveer B, Junaid N, Neha B, Amol SP. 2016. A Review update on Dillenia indica f. elongata (Miq.) Miq. Journal of Drug Delivery \& Therapeutics. 6(2): 62-70.

Arini DID. 2017. Pengetahuan lokal masyarakat Sulawesi Utara dalam pemanfaatan pohon hutan sebagai bahan obat tradisional. Jurnal Masyarakat \& Budaya. 19(2): 161-173.

Ayele TT. 2018. A Review on traditionally used medicinal plants/herbs for cancer therapy in Ethiopia: Current status, challenge and future perspectives. Organic Chemistry Current Research. 7(2): 1-8.

Bharali S, Deka SJ, Saikia P, Khan ML, Paul A, Tripathi OP, Singha LB, Shanker U. 2012. Pinus merkusii Jungh et de Vries - a vulnerable gymnosperm needs conservation. NeBIO. 3(1): 94-95.

Briliani M, Perdana MC, Perwirasari IY, Setiyaningrum IF, Giyarsih SR, Haryono E. 2018. Potency of
Curculigo capitulata and Curculigo latifolia fruit based on nutrient content (a Case for preservation need in Kebonharjo). Biotropic. 2(2): 67- 72.

Chaudhari SY, Ruknuddin G, Prajapati P. 2016 . Ethno medicinal values of Citrus genus: A review. Medical Journal of Dr. D.Y. Patil University. 9(5): 560-565.

Chavan RB, Gaikwad DK. 2016. The ethnobotany, phytochemistry and biological properties of Allophylus species used in traditional medicine: A review World. Journal of Pharmacy and Pharmaceutical Sciences. 5(11): 664-682.

Chen CY, Chiu FY, Lin Y, Huang WJ, Hsieh PS, Hsu FL. 2015. Chemical constituents analysis and antidiabetic activity validation of four fern species from Taiwan. International Journal of Molecular Sciences. 16: 2497-2516.

Damania AN. 2013. The Coco-de-mer or the double coconut (Lodoicea maldivica): Myths and facts. Journal Asian Agri-History. 17(4): 299-309.

Darmawan ARB. 2015. Usaha peningkatan kualitas mangga kasturi (Mangifera casturi) dengan modifikasi budi daya tanaman. Prosiding Seminar Nasional Masyarakat Biodiversitas Indonesia. 1(4): 894-899.

European Parliament and Council of Europe. 2006. Regulation (EC) No.1924/2006 of December 2006 on nutrition and health claims made on food. Official Journal of European Union I. 404 : 9-25.

Fruet AC, Seito LN, Rall VLM, Di Stasi LC. 2012. Dietary intervention with narrow-leaved cattail rhizome flour (Typha angustifolia L.) prevents intestinal inflammation in the trinitrobenzenesulphonic acid model of rat colitis. BMC Complementary and Alternative Medicine. 12(62): 1-11.

Glew RS, Amoako-Atta B, Ankar-Brewoo G, Presley JM, Chang YC, Chuang LT, Millson M, Smith BR, Glew RH. 2010. An indigenous plant food used by lactating mothers in west Africa: the nutrient composition of the leaves of Kigelia africana in Ghana. Ecology of Food and Nutrition Journal. 49(1): 72-83.

Hanin NF, Pratiwi R. 2017. Kandungan fenolik, flavonoid dan aktivitas antioksidan ekstrak daun paku laut (Acrostichum aureum 1.) fertil dan steril. Journal of Tropical Biodiversity and Biotechnology. 2: 51-56.

Heriyanto NM, Subiandono E, Karlina E. 2011. Potensi dan sebaran nipah (Nypa fruticans (Thunb.) Wurmb) sebagai sumberdaya pangan. Jurnal Penelitian Hutan dan Konservasi Alam. 8(4): 327-335.

Hidayat S. 2005. Ramuan Tradisional ala 12 Etnis Indonesia. Jakarta: Penebar Swadaya.

Hidayat S. 2011. Konservasi ex situ tumbuhan obat di Kebun Raya Bogor. Sekolah Pascasarjana, Institut Pertanian Bogor.

Hidayat S. 2013. Utilization of forest plants as a natural remedy by ethnic Semende, District of Muara Enim, 
South Sumatra. International Seminar Proceedings Forests and Medicinal Plants for Better Human Welfare. Ministry of Forestry, Forestry research and Development Agency, Center for Forest Productivity, Research and Development in Collaboration With National Working Group on Indonesian Medicinal Plants. Bogor, 10-12 September 2013. p. 299-306.

Hidayat S. 2017. The use by local communities of plants from Sesaot Protected Forest, West Nusa Tenggara, Indonesia. Biodiversitas. 18(1): 238-247.

Hidayat RS, Cahyaningsih R. 2017. Useful plants from Wolomeze Protected Forest, Ngada District, Florest, East Nusa Tenggara. Prosiding Seminar Nasional Masyarakat Biodiversitas Indonesia. 3(1): 56-61.

Howlett J. 2008. Functional foods: from science to health and claims. International Life Sciences Institute (ILSI) Europe Concise Monograph Series. Belgium.

Ibrahim. 2016. Inventarisasi tumbuhan obat tradisional Suku Dayak Bakumpai di Kecamatan Murung Kabupaten Murung Raya [skripsi]. Palangkaraya: Institut Agama Islam Negeri Palangka Raya.

Jarial R, Thakur S, Sakinah M, Zularisam AW, Sharad A, Kanwar SS, Singh L. 2018. Potent anticancer, antioxidant and antibacterial activities of isolated flavonoids from Asplenium nidus. Journal of King Saud University - Science. 30: 185-192.

Khasanah I, Widyaningrum A, Kusumaningtya N. 2019. Upaya peningkatan penghasilan tambahan home industri jenang cikru sebagai pendidikan berbasis pelestarian kearifan lokal di Desa Banyubiru, Kecamatan Banyubiru, Kabupaten Semarang, Provinsi Jawa Tengah. Widya Wacana. 14(1): 41-47.

Kotala, S dan N.F. Firdhausi. 2019. Keanekaragaman tumbuhan berkhasiat obat pada Suku Noaulu di Pulau Seram, Maluku. Biotropic. 3(1): 49 - 55.

Kusumawati IGA, Sugiantari NMI, Ariyasa IG, Yogeswara IBA. 2018. Identification of $\gamma$ Aminobutyric Acid (GABA) in Loloh as A Potential Drink as Antihipertension. Traditional Medicine Journal. 23(1): 23-29.

Lestari AW, Setiawati T. 2018. A Comparative Study of Morpho-Anatomy, The Content of Chlorophyll and Ascorbic Acid on Ardisia Humilis Thunberg in the Area with Different Light Intensity at the Nature Preserve of Pananjung Pangandaran, West Java, Indonesia. International Journal of Science and Technology. 3(3): 227-239.

Lumeran BT. 2016. Tissue culture of Dillenia Philippinensis Rolfe. International Advanced Research Journal in Science, Engineering and Technology. 3(9): 113-116.

Ma C, Chen Y, Chen J, Li X, Chen. Y. 2017. A Review on Annona squamosa L.: Phytochemicals and Biological activities. The American Journal of Chinese Medicine. 45(5): 1-32.

Mak C, Mok C. Molecular identification of Lodoicea maldivica (Coco de mer) seeds. 2011. Chinese Medicine Journal. 6(34): 1-5.
Moresco HH, Queiroz GS, Pizzolatti MG, Brighente IMC. 2012. Chemical constituents and evaluation of the toxic and antioxidant activities of Averrhoa carambola leaves. Brazilian Journal of Pharmacognosy. 22(2): 319-324.

Mudiana D. 2016. Syzygium diversity in Gunung Baung, East Java, Indonesia. Biodiversitas. 17(2): 733-740.

Olufemi AE, Olaniran I, Omotayo, David AB, Monjeed I, Adebola O, Bilikis S, Temitope A. 2017. Kigelia africana stem bark, fruit and leaf extracts alleviate benzene-induced leukaemia in rats. Journal of Pharmaceutical Research International. 18(2): 1-10.

Purwati E, Ristanti WE, Safitri CINH. 2018. Effect of Methanol Extract of Arcangelisia flava(L.) in Highfat diet-induced Hyperlipidemic Mice. Journal of Dental and Medical Sciences. 17(5): 55-59.

Ragasa Y, Reyes JM, Tabin TJ, Tan MC, Chiong ID, Brkljača R, Urban S. 2016. Chemical constituents of Flacourtia rukam Zoli. \& Moritzi fruit consolacion. International Journal of Pharmaceutical and Clinical Research. 8(12): 1625-1628.

Rao A, Pandey VN. 2017. Phytochemical Screening of Tubers and Leaf extracts of Sagittaria sagittifoliaL.:Newsa (Arrowhead). International Journal of Scientific and Research Publications. 7(9): 431-437.

Rifkowaty EE, Wardanu AP, Hastuti ND. 2018. Aktivitas antioksidan sirup buah karamunting (Rhodomyrtus tomentosa) dengan variasi penambahan asam sitrat. Jurnal Teknologi dan Industri Pertanian Indonesia. 10(1): 16-20.

Rowayshed G, Salama A, Abul-Fadl M, Akila-Hamza S, Mohamed EA. 2013. Nutritional and Chemical Evaluation for Pomegranate (Punica granatum L.) Fruit Peel and Seeds Powders. Middle East Journal of Applied Sciences. 3(4): 169-179.

Saleh MSM, Siddiqui MJ, Mediani A, Ismail NH, Ahmed QU, Mat So'ad SZ, Besbes SS. 2018. Salacca zalacca: A short review of the palm botany, pharmacological uses and phytochemistry. Asian Pacific Journal of Tropical Medicine. 11(12): 645652.

Salusu HD, Ariani F, Obeth E, Rayment M, Budiarso E, Kusuma IW, Arung ET. 2017. Phytochemical screening and antioxidant activity of Selekop (Lepisanthes amoena) Fruit. Agrivita. 39(2): 214-218.

Saptayana IW, Sudarsana AAGD, Sukewijaya AM . 2017. Identifikasi sebaran dan karakter tanaman Leci sebagai tanaman lansekap di tepi jalan raya Payangan, Kecamatan Payangan, Kabupaten Gianyar. Jurnal Arsitektur Lansekap. 3(1): 66-76.

Seyie Z, Saikia K, Saikia CK, Handique GK, Handique AK. 2018. Evaluation of Underutilized Cereal Crop Coix Lacryma Jobi (Jobs's Tear) for Nutritiveand Nutraceutical Values. International Journal of Agriculture \& Environmental Science. 5(4): 17-24.

Sikarwar MS, Hui BJ, Subramaniam K, Valeisamy BV, Yean LK, Balaji K. 2014. A Review on Artocarpus 
altilis (Parkinson) Fosberg (breadfruit). Journal of Applied Pharmaceutical Science. 4(08): 091-097.

Sukara E. 2014. Tropical forest biodiversity to provide food, health and energy solution of the rapid growth of modern society. Procedia Environmental Sciences. 20: 803-808.

Susiarti, S., Rahayu, M., dan M.F. Royyani. 2015. Pengetahuan dan pemanfaatan tumbuhan obat Masyarakat Tobelo Dalam di Maluku Utara. Media Litbangkes. 25(4) : $211-218$.

Varghese A, Gavania U, Abraham S, Parambi DGT, Sathianarayanan, Jose A. 2009. Phytochemical screening and antimicrobial investigation of Typha angustifolia Linn. International Journal Chemical Sciences. 7(3): 1905-1910.
Verheij VWM, Coronel RE. 1992. Plant Resources of South-East Asia (PROSEA) 2: Edible fruits and nuts. Prosea foundation.

Widiyastuti Y, Widayat T. 2013. Inventarisasi tanaman obat di Kabupaten Jayapura Propinsi Papua. Jurnal tumbuhan obat Indonesia. 6(2): 116-126.

Williams IO, Onyenweaku EO, Atangwho IJ. 2016. Nutritional and antimicrobial evaluation of Saccharum officinarum consumed in Calabar, Nigeria. African Journal of Biotechnology. 15(33): 1789-1795.

Yuliana, Fatmawati S. 2018. Senyawa metabolit sekunder dan aspek farmakologi Alocasia macrorrhizos. Akta Kimia Indonesia. 3(1): 141-158. 